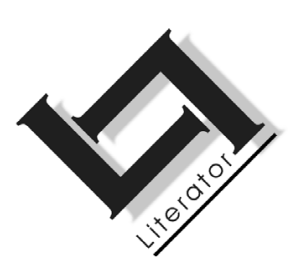

\title{
The Zimbabwean liberation war: contesting representations of nation and nationalism in historical fiction
}

\section{Muwati}

Department of African Languages

Unisa

PRETORIA

E-mail: imuwati@unisa.ac.za

D.E. Mutasa

Department of African Languages

Unisa

PRETORIA

E-mail: mutasde@unisa.ac.za

\section{M.L. Bopape}

Department of Corporate Affairs

Unisa

PRETORIA

E-mail: bopapml@unisa.ac.za

\begin{abstract}
The Zimbabwean liberation war: contesting representations of nation and nationalism in historical fiction

This article examines the array of macro and micro historical factors that stirred historical agency in the 1970s war against colonial settlerism as depicted in selected liberation war fiction. This war eventually led to a negotiated independence in April 1980. Historical fiction in the early 1980s is characterised by an abundance of fictional images that give expression to the macrofactors, while historical fiction in the late 1980s onwards parades a plethora of images which prioritise the microhistorical factors. Against this background, the article problematises the discussion of these factors within the context of postindependence Zimbabwean politics. It argues that the contesting representations of macro- and microfactors in historical fiction on the war symbolise the protean and fluid discourse on nation and
\end{abstract}


nationalism in the Zimbabwean polity. Definitions and interpretations of nation and nationalism are at the centre of Zimbabwean politics, because they are linked to the protracted liberation war against colonialism and the politics of hegemony in the state. Macrofactors express and endorse an official view of nationalism and nation. On the other hand, microfactors problematise and contest the narrow appropriation of nation and nationalism by advocating multiple perspectives on the subject in order to subvert and counter the elite hegemony.

\section{Opsomming}

\section{Die bevrydingsoorlog in Zimbabwe: botsende voorstellings van die nasie en nasionalisme in historiese fiksie}

Hierdie artikel ondersoek die reeks makro- en mikrofaktore in die geskiedenis wat die sentiment teen die koloniste laat draai het soos dit in geselekteerde romans uit die bevrydingstyd uitgebeeld word. Hierdie oorlog het in April 1980 uiteindelik tot 'n onderhandelde skikking gelei. Historiese fiksie uit die vroeë tagtigerjare word gekenmerk deur 'n oorvloed fiksionele beelde van die makrofaktore, terwyl die fiksie uit die laat tagtigerjare en daarna 'n veelheid beelde van die mikrofaktore beklemtoon. Teen hierdie agtergrond bevraagteken die artikel die debat oor hierdie faktore binne die konteks van die Zimbabwiese politiek na onafhanklikheid. Ons betoog dat die botsende representasies van die makro- en mikrofaktore in die historiese fiksie oor die oorlog die veranderlikheid en vloeibaarheid van die diskoers oor die nasie en oor nasionalisme in Zimbabwe simboliseer. Definisies en interpretasies van nasie en nasionalisme staan sentraal in die Zimbabwiese politiek, omdat hulle verbind word met die uitgerekte bevrydingsoorlog en die politiek van staatshegemonie. Makrofaktore druk 'n amptelike beskouing van nasionalisme en die nasie uit en onderskryf dit ook. Andersyds problematiseer mikrofaktore die eng toeëiening van die nasie en nasionalisme, want dit druk veelvuldige perspektiewe op die onderwerp uit wat die hegemonie van die elite teenwerk en ondermyn.

\section{Introduction}

The central concern in this article is the Zimbabwean writers' conceptual recreation of the array of macro and micro historical factors that galvanised various characters to partake in the liberation struggle in the 1970s. It problematises the discussion of these factors by reading them as fictive historiographical representations which must be conceptualised as signifiers to fluid and protean discourses on nation and nationalism in Zimbabwe. Nation and nationalism are 
sites for vigorous intellectual contestations between the ruling minority on the one hand, and the majority of the so-called ordinary people in Zimbabwe on the other hand. As Ranger (2005:217) observes: "Nationalism as a movement, or set of movements, and as an ideology, remains central to contemporary Zimbabwe and still requires a great deal of rigorous historical questioning." Consequently, the fluidity of the definitions of nation and nationalism as seen through the prism of macro and micro factors defies any barricading in morbid, static and monolithic reconstruction of narratives of liberation history which unfortunately have been used as fountains for political absolutism in independent Zimbabwe and elsewhere in Africa.

In this regard, historical fiction under exegesis negotiates and renegotiates the historical terrain and the national discursive narrative thereby contributing to the opening of multiple centres and vantage points from which to appreciate the use of the political/historical past in the politics/history of the present, because "history is at the centre of politics in Zimbabwe far more than in any other southern African country" (Ranger, 2005:242). For that reason, this article further shows that the incipient ideological contestations of nation and nationalism as shown through the lenses of macro and micro factors reflect the balance of power and the shifting of power in the Zimbabwean polity. We also argue that this creative version significantly reflects the fragile and contestable character of the nationalist ideology and the definition of nation after independence in 1980.

Corroborative evidence for this critical enterprise is drawn from narratives written in all three of Zimbabwe's literary languages namely, Shona, Ndebele and English. By focusing on historical fiction in different languages, we intend to "include the role of ZIPRA as well as the role of ZANLA, to extend the grassroots studies of the war from Manicaland and Mashonaland into Matebeleland" (Kamba quoted in Bhebe \& Ranger, 1995:1). The struggle for independence in Zimbabwe was a collective enterprise whose national character equally mandates expression in critical scholarship. We feel that the ability to appreciate the national character of the liberation war in Zimbabwe in all fields of research and from plural and multiple centres is a pedagogically empowering experience as well as an aesthetically ennobling enterprise that guards against the narrow containment of public memory. This is the case, because this war is

... a history of the people who suffered and died, and of those who survived to witness the birth of a new Zimbabwe. It is a history of all the people of Zimbabwe - the big and small, the 
rich and the poor - with no particular concern with those who were or are in leadership positions. (Dumbutshena quoted in Auret, 1992:vii.)

Yet attempts have been made by a few political figures to privatise the war/history. The narratives under discussion have been selected on the basis that they constitute a representative sample of trends in war fiction published in the three languages as well as different historical epochs. These historical epochs are divided into the early 1980 s and the late 1980s and beyond. Historical fiction published in the early 1980 s is published in association with the Literature Bureau, a government-funded department tasked with overseeing the publication of fiction in Shona and Ndebele. In other words, the continued presence of the Literature Bureau which had been in existence since 1954 potentially helped in maintaining a tradition of selfcensorship and "formal censorship, which was not often used" (Kaarsholm, 2005:4). Partly against this background, this fiction articulates a state-centred perspective of history by remembering the heroic and so-called patriotic side of history. Historical fiction published in the late 1980s, particularly fiction published in English questions and critiques official narratives while confronting the tendency by the ZANU PF government "to prevent other [alternative] pasts from articulating themselves" (Alexander, 2006:105).

\section{Historical fiction}

The article situates Zimbabwean liberation war fiction within the ambit of historical fiction/narratives. Historical fiction imaginatively and creatively recreates a people's past and their history drawing inspiration from real life historical experiences. It is a creative artistic intervention and discursive instrument for negotiating the thin line between the past, the present and the future using images, characters and symbols as embodiments of historical action and memory. The creative element gives fiction the leverage that orthodox history does not usually have since creativity involves more than recording or capturing events. The creative aspect that underpins fiction production qualifies it as a critical tool in negotiating human experiences. This realisation has been presented elsewhere as follows:

The arts are the most immediately recognizable form of creativity. All art deserves laudation as the representative of the concept of creativity ... Yet while the arts are among the highest forms of human activity, they grow out of the soil provided by the more modest routines of daily life. They provide people with 
opportunities to consider and communicate their reality and visions in new ways. (UNESCO, 1995:81.)

Writers who conduct dialogue with the community through historical fiction are part of the call that

[w] cannot take [readers] on a field trip into the past, but we can recreate a sense of history so powerful that [they] enter imaginatively into the past and explore 'the conflicts, suffering, joys and despair of those who lived before us'. (Huck, 1977: 469.)

In this regard, historical fiction must be as close to the source of history as possible if it is to have any value to the intended consumers. This finds corroboration from Freeman and Levstik (1988: 331) who explain that

[h]istorical fiction - and history - is more than a simple retelling of past events. Rather historical fiction is part of an ongoing process of interpretation in which [readers] can participate. Our suggestions are intended to encourage comparisons between historical fiction and the data from which historical explanation emerges.

The same conceptual scheme finds expression through Mensah (2004:69) who explains that

... the purpose of the historical novel is to make the reader experience the psychology and ethics of the past, not as a curiosity, but as a phase in mankind's development which is of concern to the reader. The historical novel ... provides a tangible human portrayal of the historical trends of an epoch.

The historiographical value of historical fiction cannot be underestimated as it significantly contributes towards a better understanding of a given historical era. Nonetheless some sections of society find this assumption repulsive and naive. With regard to these, Motsa (2006:13) confirms our suspicions and at the same time unambiguously affirms the value of historical fiction.

Certain members of society may not even believe that literary creations can create and narrate 'history' from alternative sites as well as authorize versions of 'literary history' that can interrogate official historical accounts.

While it is not the subject of this discussion to show the authenticity of historical fiction, except through insinuation, the distinction between fiction and history can be dealt with using investigative and 
analytic parameters such as authenticity, narrative syntax, involvement and intention of the author as well as audience reception of the texts among others (cf. Fleischman, 1983).

\section{Macro factors for joining the liberation war}

Historical fiction in the early 1980s, the period when Zimbabwe attained its independence, largely parades a preponderate commitment towards articulating the macro or nationalist inclined factors. This is particularly the case with fiction that discusses the combatants' experiences. In this category, the micro factors, though present, are remarkably subsumed under the macro ones. At the same time, the war in these novels is seen from a nationalist vantage point glorifying the nationalist ideology. In the early 1980s, the abundance of fictional images depicting macro causes, particularly land, patriotic consciousness and segregation, reflects the impact of the nationalist and socialist ideologies of the time. During this period, the writers' attitude towards nation and nationalism is couched in celebratory terms and what Ranger (2005:220) calls "patriotic history" which "resents disloyal questions".

Generally, the early 1980s was a period of independence euphoria and the attempt by the ruling elite to consolidate its power. As Moyo (1993:7) says,
ZANU(PF) declared 1981 as 'the year of the consolidation of people's power' which, according to the President of ZANU(PF), Robert Mugabe, impelled the ruling party to 'adopt a more comprehensive and a more generous view of Government ...' The need for such a comprehensive view of government was interpreted by the ZANU(PF) leadership and supporters to mean the establishment of a one-party state.

It was also in vogue to see the war as a people's collective history of struggle against varying forms of oppression, particularly white racist rule. Consequently, nationalist or macro causes became a celebration of the nationalist ideology as the driving engine behind the struggle for the birth of the new nation. They underline the new nation's concerted search for national symbols and its attempt to establish and discursively construct a purely national and shared identity all vital in nourishing and sustaining political legitimacy. Historical fiction in this section underscores the traditional and official conception of nationalism by merely pontificating about the collective love of nation. It builds a case for great nation builders whose penchant for national liberation is said to be unrivalled. Among such 
great nation builders are the nationalist leaders who have conferred upon themselves inimitable and ostentatious titles as founders, souls and fathers of modern Zimbabwe.

Nationalism was one of the ideological strategies for stirring active political consciousness. The marketplace view of nationalism makes it essentially an anticolonial ideology. It has continued to be viewed thus in elite circles (ZANU(PF) leadership) in Zimbabwe. According to Alexander et al. (2000:6) "nationalism embodied the ideas of freedom, democracy, equality and restoration of the land to the people of Zimbabwe". In the context of the liberation war in Zimbabwe, nationalism further needs to be understood from two angles, both complementary. Firstly, nationalism arises from people's identification and affirmation of their indigenous cultures and knowledge systems. In this context, it becomes an innate feeling that is not superimposed on a people from outside. It is not a phenomenon introduced from outside or above. People themselves embody, construct, direct and provide the blazing embers for its manifestation. Secondly, it gained its impetus from a cocktail of foreign ideologies including Marxism and socialism. This then implies that nationalism was a combination of both indigenous and foreign values seen as progressive.

It is also important to point out that so far the liberation war fought in the 1970s has been made the singular expression of nationalism in Zimbabwe. This view which has been maintained by the elites has narrowed the conceptualisation of nationalism such that any other political or ideological perspective which has nothing to do with the liberation war is met with violence by the nationalist party, ZANU(PF). The idea of nation has also been restricted to this understanding of nationalism to the effect that those who seek to define nation differently, become what the elites call puppets and stooges of the West. For instance, the views from Ranger (2004) and Alexander (2006) quoted in Alexander (2006:114) concretise the above.

In the parliamentary elections of 2000 and presidential elections of $2002 \ldots$ ZANU(PF) was cast as the sole representative of the liberation movement and African authenticity, while the MDC 'had abolished history', proclaiming its irrelevance in an 'age of globalisation'. They merely promised prosperity and were prepared to 'reverse' Zimbabwe's history in order to achieve it, even if this meant 'turning Zimbabwe into a British and American overseas territory'. The MDC's leader Morgan Tsvangirai 
was attacked for not having contributed anything to Zimbabwe's history, and indeed not understanding what it was.

Numerous symbols that identify the nation are covertly and overtly linked to the nationalism of the 1970s. Examples include the national flag which has a red strip that represents the blood shed during the war, the national heroes' shrine in Harare, the national coat of arms and the new national anthem which replaced the pan African Ishe Komborera Africa/Nkosi sikelela iAfrica (God bless Africa).

During the colonial period, and particularly in the 1950s and 1960s, a number of African political formations such as the Southern Rhodesian African National Congress (SRANC), National Democratic Party (NDP) and Zimbabwe African People's Union (ZAPU) became actively involved in rallying people together. According to Dabengwa (1995:25), both these organisations appealed to and had membership across ethnic and tribal groupings throughout the country. At that time the language one spoke did not matter. People made a conscious effort to understand languages other than their mothertongue. The unity of the people against settler rule was taken for granted. Everybody was referred to as mwana wevhu (son of the soil). This Shona phrase was untranslated, because its meaning was comprehensible to all.

In the context of mass mobilisation, the nationalist ideology supposedly provided a seamless rallying point in which all the people combined their energies to come to the defence of their nation. They were motivated by personal sacrifices nourished by an incorruptible sense of patriotic national duty. All black people were therefore supposedly united by their collective hatred of the colonial master and the need to reclaim their heritage. In the words of Hoffer (1955: 129), this collective defiance against the white minority was precipitated by such colour-conscious realisations like "we are united by hating in common and being hated in common". The assumption was that all black people were victims of racialism and other debilitating Rhodesian machinations.

Consequently, most war fiction writers writing in the early years of independence when the mood is that of nationalist euphoria generate images where people went to war because of the love of their nation as well as the love of liberation. The characters symbolise patriotic heroes and heroines who sacrificed their lives for the liberation of Zimbabwe. One of the macro causes is presented as land. As a macro historical resource, land has continued to be the rallying point for resuscitating and remembering and re-membering 
the nationalist ideology particularly in times when it is threatened by new political currents. Kriger (2003:195) observes as follows:

In the June 2000 parliamentary election campaign, ZANU(PF) again targeted its violence and intimidation on the rural majority. White farmers, African farm workers ... all became prime targets because they were suspected to be MDC supporters ... Invasions of the white-owned commercial farms began soon after a referendum in early February 2000, in which 55 percent of those who voted rejected the government's proposed constitution. Led by war veterans, land invasions were a deliberate attempt to place intimidating party campaigners close to their rural targets.

Sigogo (1986), a Ndebele writer, depicts patriotic consciousness and sacrifice for the nation as part of the main factors that prompted people to take up arms. Land is one resource that provided a platform for such patriotic commitment. His novel, Ngenziwa Ngumumo Welizwe (I was influenced by the political situation), is "inspired by one serious dimension of the ZAPU side of the war, namely, its emphasis on recruitment of personnel in preparation for a conventional war against colonialism" (Chiwome \& Mguni, 2003:139). It chronicles how the advent of the war impacts on two lovers' personal plans. Lisho is a teacher at Wanezi and Phikezelwe, the girlfriend, works in a bank in Bulawayo. Lisho seems to be ignorant of the evils of the colonial system and is mainly preoccupied with his personal ambitions. On the other hand, his girlfriend is deeply entrenched in the crucible of the politics of the time. As the war intensifies, Lisho takes up a job in Bulawayo despite protests from his lover and brother, Ntakana. When he is called up for military service under the Rhodesian forces, his lover abandons him and their affair collapses. Phikezelwe escapes from prison after she had been captured and she goes to train as a freedom fighter. The two are therefore fighting on different sides. Eventually, Lisho decides to join the freedom fighters.

During a discussion between the two in which their views are diametrically variant, Phikezelwe says:

Mina, Thobela, angikwesabi ukubotshelwa ukufuna ilizwe lethu. Ngitsho lakho ukulifela mina angikwesabi. Kimi kungcono lokho kulokuthi ngiphilele ukuba yinja lesigqili sabanye abantu! (Sigogo, 1986:73.) 
As for me, Thobela, I am not afraid to be persecuted for wanting our country. I am not even scared to die for it. To me that is even way better than living as other people's dog and slave!

The Zimbabwe-is-larger-than-life current is unmistakable. It is this political philosophy that nourishes nationalist thinking. Such individuals who feel that they went to war because they loved Zimbabwe more than anything else are likely to find it difficult to countenance any other perspective towards nation and nationalism. The same attitude leads to straitjacketed thinking that leads to a fossilised and ossified imagination of history and national politics. Phikezelwe's determination to sacrifice for the national cause typifies the patriotic version of history and the nationalist disposition of some Zimbabweans who had been marginalised by colonialism. She typifies the nationalist figures in contemporary Zimbabwe who have personified nationalism and nation by offering and encouraging, even through violence, what Ranger (2005) calls patriotic history. Phikezelwe is selfless, unlike her lover - an average African intellectual of the time who is obsessed with personal goals and plans such as work and marriage. As a civil servant working for a government publishing department, the Literature Bureau, Sigogo (1986), the author, portrays images of sacrifice that are consistent with the ruling elite's version of the war. Violence against the opposition parties since the attainment of independence in 1980 is meant to protect this elite or monolithic view of patriotic history.

In an emotional exchange with her lover, Phikezelwe also draws his attention to the marked discrepancy between areas reserved for whites and those meant for blacks. At the same time, she also chronicles the discriminatory tendencies that made people like her sacrifice their lives. Sigogo says:

Waqhubeka uPhikezelwe wamlandisela ngokwakusenzakala lapha ayesebenza khona - ukuphakanyiswa kwabelungu ngesikhatshana kodwa yena labanye abamnyama belokhu betshudula ndawonye okweminyaka engaziwayo. Wachaza ngokwakusenzakala emafekithari lakwezinye izindawo. Wangena lasezikolo wamcubungulela ngokwahlukana okwakukhona phakathi kweholo lamatitshala amhlope lamnyama. Wangena emapulazini abamhlophe waqathanisa ukuvunda komhlabathi wakhona letshebetshebe lasezabelweni zabantu abamnyama. Wasebuzake esithi, 'Yikho othi ngiphilele ukukubona ngithule kuze kube laphakade konke Lokhu?' (Sigogo, 1986:73.)

Phikezelwe went on to outline to him what happened where she worked - the promotion of white employees within a short 
period of employment while she and fellow black workers toiled endlessly without any elevation. She went on to lament what happened in factories and other places. She touched on the educational institutions and examined how differently the salaries for black teachers were pegged from those of white teachers. She contrasted the fertility levels of soils in whiteowned farms with the sandy soils in the areas reserved for black people, and proceeded to ask, 'Is that then what you ask me to live for, and be mum about it for an eternity?'

The rampant racialism in Rhodesia as seen by Phikezelwe partly resonates with evidence provided by Davies (1975:382).

In June 1971 a statement on the new salary scales for teachers was issued. These made a distinction between the salaries of standard qualified teachers in the Public Service (the schools directly operated by government which are nearly all for Europeans) and those in the government-aided schools, the United African Teaching Service. As most teachers in government schools are Europeans, and would therefore get higher salaries than their counterparts in the non-government (state-aided) schools ...

Blacks were disadvantaged, because they were considered an inferior race. As a result, they joined the war to put an end to the system that denigrated them. The overarching goal was the liberation of the country and its people from colonial bondage. Racial discrimination becomes a factor that affected most blacks living in Rhodesia. It therefore caused the oppressed to sacrifice their lives for a new dispensation. Instead of disarming and handcuffing African resistance, it actually fuelled the desire to eradicate it so that African people would regain control of their destiny.

As reflected in Phikezelwe's acute consciousness above, it is also clear that land and other resources became a major factor for rallying national consciousness. The repressive state policies on land find vindication from Caute's (1983) account of the impact the Land Apportionment Act had on land ownership patterns between blacks and whites.

By the Land Apportionment Act of 1931 some 6,000 European farmers (including foreign-owned giants like Anglo-American, Liebigs, Lonrho and Hallets Corporation) were granted exclusive custody of almost half the country's land. Evictions continued. Between 1936 and 1959, 113,000 Africans were forced to quit areas reserved for Europeans ... . By 1979 there were 1.6 million hectares of unused land in the commercial 
farming areas while land famine prevailed in the reserves, where 675,000 black peasant farmers and their 3 million dependants crowded into 17.6 million exhausted hectares. (Caute, 1983:80.)

Such injustice undermined the dignity of African manhood and womanhood. It degraded the African by condemning him/her down the precipice of poverty. Other historians such as Alexander et al. (2000) are more specific about the gravity of the land issue as a rallying point for nationalist action in areas of Matebeleland (which Sigogo (1986) writes about). Alexander et al. (2000:85) write:

Focusing on the state as the source of oppression and discrimination, Shangani nationalists went beyond opposition to particular legislation, such as the Land Husbandry Act, or particular official interferences, like contouring. They developed an ideology of their rights, as citizens of an African nation, to land and resources, to dignity and freedom.

Land and the love of the nation become a prominent factor that made people participate in the liberation struggle.

Mabhunu, a character in Makata's Shona novel, Gona reChimurenga (1982) (Champion of the liberation), is a super-patriot who sacrifices his life for the liberation of the nation and its resources. The story centres on the indomitable nature of three guerrillas whose exploits lead to the liberation of masses in reserves like Murehwa and Macheke. It deifies the gun as the ultimate liberator from the tentacles of colonialism. Mabhunu, the central character, advertises his patriotism thusly:

Ndakange ndazvipira kufa, kufira nyika, kufira upfumi hwayo, kudzora zvese zvakapambwa ... (Makata, 1982:20).

I had offered to die, to die for the country, its wealth as well as recovering everything that had been taken by force ...

The commitment and patriotic tenor expressed here underlines the nationalist temperament which puts the nation first. As already underscored, this vision largely characterised part of the celebratory literature of the early 1980s. Writers, being the sensitive minds of their time, advance a creative consciousness that heightened nationalist sentiments. The message was that the new nation was born against the background of a shared commitment, shared history, shared vision and national agenda. It is also this sacrificial and collective awareness that characterises Phikezelwe's vision in the context of Rhodesian politics. Phikezelwe and Mabhunu, therefore, 
become political symbols that radiate and disseminate a nationalist patriotic consciousness. They transcend narrow obsession with personal interests. Such a macro approach to history in which the few patriotic and great figures fought and sacrificed for the rest of the citizens leads to the narrowing and closure of the political space.

Nationalist patriotic consciousness is the same philosophy advanced in Moyo's Shona novel, Nguo Dzouswa (1985) (Upheavals), in which Kudzai, the central character and heroine, sacrifices her family for the nation. Nguo Dzouswa focuses on the family of Kudzai and her husband, Andrew Mukombachuru. Kudzai lives and works in the rural areas as a nurse and is a staunch supporter of the guerrillas. Her husband who lives in Harare is one of the leaders of an urbanbased party that backs the Rhodesian government. As a result of their different political persuasions, the two clash and Kudzai leaves for Mozambique. The novel ends with a landslide victory for Kudzai's party (ZANU(PF)) and the two reconcile as husband and wife.

In the novel, Kudzai's love for the nation is greater than that for her family. She even leaves behind her young son so that she can take up arms to liberate Zimbabwe. Zimbabwe supersedes the welfare and integrity of her only child and husband. She asks herself rhetoric questions that manifest the depth of her love for the nation. "Asi ndorega kuenda kuhondo kundorwira kusunungura povho yose napamusana pemwana uyu here?" Shall I not join the war to liberate the majority of our people because of this child? (Moyo, 1985:114.) Certainly this attitude makes her a super-citizen. She is different from the rest who have to be liberated by such selfless and patriotic personalities. It is this attitude that seems to inform the Zimbabwean political elite who feel that they liberated the povho (poor majority) and as such they can continue to patronise them. It is also an attitude that bestows historical and moral agency in the state on a few citizens. It sets the stage for, and justifies the domination of the majority by the minority. This creative version which typifies most of the early 1980s literary histories can be seen as "a ready-made model of ... history that is written 'from above', in other words, history that is seen as resulting from the doings of one great leader" (Mensah, 2004:70, 77).

After she has gone, she informs her husband, Andrew, in a letter that "Ndine rudo rukuru kwauri asi rudo urwu rwatadza kusvika pano rwandiinarwo kuZimbabwe" (I have great love for you but this love has failed to match the love that I have for Zimbabwe). Apparently, Kudzai has all the comfort that she needs in life. By sacrificing for the "povho" (poor majority) she becomes a super-patriot. Such 
literature becomes a national memorandum conveying the message that it was out of sheer selflessness that both peasants and youths took an active part in the struggle. While the author depicts the subversive impact of the liberation war on the average Shona family, his vision is directed towards the construction of patriotic female heroines. He also advances the ruling party's (ZANU(PF)) position on gender where women are said to have played significant roles in the war by fighting alongside their male counterparts. However, history does not fully vindicate this version as shown in NhongoSimbanegavi (2000). For instance, Nhongo-Simbanegavi (2000:2-4) says:

ZANU had enough 'proofs' of female emancipation, upon which it could congratulate itself. The pictures showed women in trousers, marching aggressively with their guns - the living testimonies of the Party's success in a great revolutionary experiment ... Many scholars succumbed to these high-sounding declarations and accounts given by ZANU's publicity organs ... When researchers have used this propaganda, the resulting histories have sometimes been quite alien from the real life experiences of those concerned. Some women written about have not even been able to recognise themselves in these rather too scholarly accounts.

At the same time, the clear message is that the war was fought by patriotic people who were motivated by the love of Zimbabwe. Essentially, such images were meant to recast nationalism in positive terms. They functioned to varnish and camouflage the pitfalls of national consciousness which had threatened to derail the progression of the war. Such pitfalls are manifest in Sithole's phrase, "struggleswithin-the-struggle", which is also the title of the book (Sithole, 1999). The new black elite in leadership positions encouraged such an image of the heroic and gallant nationalist history as it could be used in justifying national unity and promulgating patriotic history. It also justified the liberation war as a people's war and the commemoration of liberation war nationalism as the sole legitimate political brand that could lead Zimbabwe. It would not be a far-fetched intellectual assumption to read the monolithic view of nationalism as the ongoing concretisation of a one-party system. In the words of Muponde and Primorac (2005:xiii) macro causes are part of the "officially-sanctioned national identities" on "patriotic history". 


\section{Micro factors for joining the liberation war}

Liberation war fiction in this discussion written in English and published in the late 1980s and partly fiction in Ndebele and Shona published from approximately 1990 onwards largely parades images that give voice to micro or individual causes. These emblematise "an alternative historical narrative capable of displacing patriotic history" (Ranger, 2005:240). The stuttering official nationalist narrative is subjected to cantankerously vituperative reviews and criticisms. Group symbolism, which informs the patriotic nationalist discourse as evinced through the prism of macro factors is gradually discarded in favour of individualist discursive consciousness actualised through micro factors. Focus on the individual and the micro factors in general, become a critique of the official nationalist ideology whose powering engine is the group. It is a subterranean representation of the renegotiation and demolition of hegemonic power particularly in a political context where "all 'legitimate' organizations were challenged by ZANU(PF) to join the ruling party as a way of proving their revolutionary and patriotic commitment" (Moyo, 1993: 7 ). It also marks the radicalisation of alternative and counter voices to insipid ruling elite dogma. Such counter-discursive perspectives amplify the imagination of multiple versions of nationalisms and "multiple versions of [nation] Zimbabwe" as a counter-hegemony initiative. Fictional images in these works indicate that people did not simply join the war because they were indefatigably patriotic, loved land and supported national or universal liberation. They joined the war for reasons other than nationalism; among them evading criminal justice, escaping poverty and squalor at home as well as falling prey to abduction. In this regard, it can then be submitted that

literature possesses the capacity to produce certain patterns of meaning and truths of their own which do not necessarily subserve claims of conventional history. The histories and truths that literature tells ... sometimes ... reject the protocols of representation of social processes captured in nationalist romances. (Motsa, 2006:13.)

Many factors are attributable to such a creative modality where micro factors as well as the predisposition to counter nationalist romances are canonised as thesis. Among them are the economy and general disillusionment with independence, a shift in political ideologies as well as the passage of time which affords writers both creative and critical space to review, reconfigure and redefine and renegotiate the historical turf outside the context of celebration. Generally, the late 1980s and the 1990s were characterised by 
growing frustration with the ZANU(PF) government. Rampant corruption, unemployment and increasing levels of poverty became the order of the day. Alexander (2006:108) clearly describes the mood in this period:

The ruling elite's developmental programme, which was an important source of its legitimacy, came under angry criticism, as did its claims to the nationalist mantle. History was a heated focus of debate and challenging official narratives was a powerful means of making claims on the state and politicians.

The introduction of the Economic Structural Adjustment Programme (ESAP) worsened the situation as inflation rose putting food prices beyond the reach of many people. This culminated in violent demonstrations against the government which was accused of mismanagement. The former guerrilla fighters also confronted the state accusing it of neglect and in 1997 "they responded to the 'looting' of official war compensation funds by the political elite with protest and riot" (Alexander, 2006:108). In this regard, it can also be said that English war fiction writers begin to use fiction as a discourse of protest and "history as opposition".

This version of history is also attributable to the attempt by sidelined demographic categories to invest in the discursive terrain of national historiography by contesting an indigenous "imperialism of discourse" manifest through the narrow appropriation of nationalism and nation by those in political office. Ranger (2005:219) seems to vindicate this supposition when he writes that, ordinary

people had been denied a history. But you could have too much history as well as too little. You could have too much history if a single, narrow historical narrative gained a monopoly and was endlessly repeated ... Now it had become necessary to complicate oversimplification; to offer a plural history.

The critical discourse thus reflects the growing criticism of nationalism in the nation.

The Rhodesian system curtailed and transgressed on human liberties and dignity. Most African institutions that were critical for harmony, balance, and synergic interactive behaviour were either destabilised or completely destroyed. The family was one such institution whose integrity and significance on communal harmony and normal child development was seriously compromised. The collapse and corruption of the family as a fundamentally constituted rallying point and controlling consciousness for the national agenda meant 
foreign values totally incompatible with the lived experiences of the Shona and Ndebele people crept in. Coupled with this, was the intensification of social, political and economic oppression which led individuals to make unusual choices in a changing and dehumanising context. Some of the choices included what the Rhodesian system called crime as well as other forms of juvenile delinquency.

It is against this background that writers view the experiences of young people who eventually decide to join the struggle. Some individuals cross into neighbouring countries to join guerrilla armies in order to escape prosecution and persecution by the Rhodesian system. The war becomes a safe haven for lawbreakers who also cannot countenance the wrath of their parents and the Rhodesian system. Such individuals who are forced into the war by criminal reasons and agendas other than African nationalism and African majority rule (Kriger, 1992:170) include Benjamin in Chinodya's Harvest of thorns (1989), Donald, Charles and Alexio in Mazorodze's Silent journey from the East (1989).

Benjamin in Harvest of thorns (Chinodya, 1989) grew up in a family harangued by excessive religious dogmatism. His parents' blind following of Christianity denied children freedom of choice, movement and association. They were, therefore, brought up in a superficial world that somehow conflicted with events taking place at the time. Life at home was different from life at school. It is this conflict of interests that leads Benjamin to openly revolt against his parents. When he accidentally hurts Peter's leg, this is attributed to evil living inside the young man. He is also forced to take part in burning a township beer hall and is subsequently arrested. He is caned and released after a stern caution that he should not participate again in an offence of the same nature. When he goes to Goromonzi High School for secondary education, he is forced to take part in demonstrations against forced conscription of blacks into the Rhodesian army. He is arrested. He escapes at the slightest opportunity and goes to Mozambique. Benjamin's experiences reveal that he does not join the war out of love of the nation or patriotic consciousness. $\mathrm{He}$ does so for personal and individual safety.

He becomes a fugitive who takes refuge in the war. Increasing focus on the individual dissects the nationalist myths which emphasised the notion of group. When one looks back, it becomes clear that Benjamin could not possibly fathom the thorough and determined beating he would get from his father. Secondly, he was already on the regime's criminal record of people who had committed politically related crimes. As a result, he escapes from possible prosecution 
and persecution. Thirdly, he has to escape from an environment where everyone accuses him of having single-handedly contributed to the amputation of his brother's leg. In this regard, the criminalisation of nationalist agency in the novel is intended to function as a counter voice to the official nationalist narrative where patriotic consciousness is endlessly repeated.

For that reason, Harvest of thorns becomes a deconstruction of official hagiographical versions of personal and patriotic sacrifices for the nation and the majority of the people. It dismisses the grand narratives that parade national patriotic consciousness as the only force that galvanised historical agency. It problematises discourses on nationalism, the uses to which they have been put as well as the interpretation of nation. The novel becomes a vigorous contestation of the nationalist ideology by offering alternative and potentially "divisive narratives of war". Where the state-centred narratives emphasise unity, Harvest of thorns underscores individuality. Such discourse on national unity has been used as a political tool in the subtle disempowerment of ordinary people who have been encouraged to observe unity on the basis of official sacrifices in the war. In this context, those individuals who would dare say something outside the group become saboteurs and unpatriotic. By shifting focus from the group to the individual, the author evinces that the discourse on nationalism and nation is far from being commonsensical and cannot merely be imagined on the basis of the collective and the selfless as the sole legitimate conceptual fountains. As shown by Kaarsholm (2005:4) this observation leads to another realisation.

While there is no doubt that literature and writers may work to transmit ideology and help keep people's minds in bounds, they are also important in building democratic potentials from below, and in destabilizing powerfully established structures of mental authoritarianism.

The urge to escape from possible prosecution because one has committed a serious crime, provides a counter ideological and intellectual framework through which the nationalist discursive narrative is questioned. The questioning amounts to criticism of the ruling nationalist elites who derive their legitimacy from controlling public memory. In this regard, the emphasis upon the micro factors in Harvest of thorns proffers alternative versions of nationalism and discourse on nation in Zimbabwe. Fiction becomes a 
... welcome intervention in the debates on nation, narration and national consciousness ... [Chinodya's] conscious use of language to destabilize ways of seeing and interpreting a reality that has become commonsensical [historiography is an intellectually satisfying position that] shows that identities are not static ... but are constructed as shifting, slippery, embedded in fragile ways within the language of representation (Motsa, 2006:14-15).

In the same vein, three friends in Silent journey from the East (Mazorodze, 1989) also join the war because one of them, Donald, a physically bulldozing and yet psychologically diffident boy, has murdered two people, an old man and his daughter. The gravity of the crime and the concomitant punishment coerces the three to go to Mozambique to join the freedom fighters. The author explains as follows:

Donald had nothing on his mind except escape - not even the journey in front of him - he had to get away from the police. He had no company in his heart, only two humanoid creatures helping him escape. He would not hesitate to destroy any one of these creatures if they came between him and his safety. Yet his second greatest worry (the first being safety) was that he had no courage to go anywhere without them - he did not know how to escape. (Mazorodze, 1989:9.)

While it is Donald who delivered the murderous blows, Alexio and Charles are overwhelmed by the contagious effect of the serious crime considering the closeness of their relationship. Alexio, for instance is numbed with self-immolating helplessness in the face of the crime committed by Donald. "He felt himself losing the zeal for life as he saw himself sinking deeper into a very criminal affair in which he had no chance of ever proving himself innocent." (Mazorodze, 1989:26.) The two are literally drawn into the war by the pugnacious Donald and the need to escape from a serious crime.

Evidently, Mazorodze ascribes participation in the war to micro and personal factors. The threesome are victims of juvenility. They are unconsciously propelled into the war by their variant yet complementary youthful traits. It is not out of any conscious preparedness and patriotism and love of the country or its people that they join the war. Writers who publish years after 1980 contest the official view of nationalism and nation by articulating the micro factors. The fullspirited abandonment of the macro factors by fiction writers also becomes a protest against the ruling elite's tendencies to contain historiographical material and truncate the discursive intellectual and 
political space. Claims to a monolithic national discourse on the war and nation have been used as invidious justifications for a hotchpotch of control mechanisms that have marginalised the majority of Zimbabweans. In this context, nationalism has been used as "a bizarre graft of carefully selected historical incidents and distorted social values intended to justify the policies and actions of those in power. At the same time development [has been] seen in the reductive sense." (UNESCO, 1995:94.)

The contest between macro and micro causes in Zimbabwean liberation war fiction reflects an ongoing contest of ideas and hegemony between the ruling elite and the generality of the citizenry. In this context, therefore, nation and nationalism are vigorously contested sites between the ruling elite and the majority. This has been engendered by the conscious realisation that nationalism has been divested of its national appeal to a point where it has become a cocktail of warped self-seeking manoeuvres and a justification for minority power. The narrow conceptualisation of nationalism has led the majority to feel they are not part of the broader national entity. Fiction writers like Chinodya, Mazorodze and others who give voice to micro factors are concerned with renegotiating nationalism by offering alternatives. Historical fiction on the war becomes a veritable stakeholder in the ongoing struggles against the nationalist party, ZANU(PF), which has presided over a crumbling economy, unexampled humanitarian crises and increasing state violence.

Phillibon, a character in Clement Chihota's (2000) short story "When the baobab gets fat" in No more plastic balls is stampeded into the war as an act of escaping from possible arrest and conviction. It is said that he always quarrelled with his employer "about his pay until he disappeared one day after stealing a whole leg of beef. He went to join the liberation struggle" (Chihota, 2000:124). As indicated before, the war becomes a safe zone for people who wanted to avoid jail. People joined the war for reasons other than nationalism. A former guerrilla commander, Keven Masango operating in the Gutu area, southwest of Zimbabwe, is said to have remarked to one Catholic Sister Josephine "that not all who joined the struggle were good people" (McLaughlin, 1996:232). Yet the view of nationalist history that has been institutionalised in Zimbabwe is that all those who joined the struggle were patriots.

Daniel, an eighteen year old young man in Pawns (Samupindi, 1992) joins the war in order to escape from poverty and squalor at home. He lives a life punctuated by mortifying and self-immolating embarrassment. After the tragic death of his father in a car accident, 
the family loses its sole breadwinner whose meagre income of $\$ 35$ a month had made the family's living standards fairly comfortable. As the eldest child in the family, he is expected to contribute towards the general welfare of the surviving children and his mother. However, it is the mother who has to struggle by selling vegetables to feed the whole family and send them to school. At times the mother comes back empty handed, because the vegetables would not have been bought. As a result, the family, including Daniel, goes to bed without having eaten anything and during these times, the mother would wish her husband was alive. This seriously affects Daniel as it undermines his dignity and essence as a human being.

Pawns (Samupindi, 1992) is a novel that is difficult to simply categorise as fiction. The writer, who is a former combatant, uses real life experiences and names from the liberation war. Two striking cases are Mugabe and Tekere's escape to Mozambique, the role of Nyafaru farm and its directors Guy and Molly Clutton-Brock of Cold Comfrot farm (Davies, 1975:264) as well as the Monte Casino battle which historians like Moorcraft and McLaughlin (1982) have comprehensively documented. Reading Samupindi's Pawns (1992) and McLaughlin's (1996) On the frontline: catholic missions in Zimbabwe's liberation war inevitably make one feel that historical fiction and history are inseparable, because the semblance is quite striking. Daniel's encounter with Robert Mugabe in Highfields and the subsequent journey to Nyafaru farm, the assistance they got from the Catholic sisters and their sojourn at Nyafaro farm is all part of history.

In the novel, the family's debased condition traumatises Daniel. Among the Shona people, the eldest child is burdened with the inescapable duty of fending for the family and ensuring its continuity in the absence of the father. Daniel cannot fulfil any of these. At his age, he moves around dressed in tattered and patched clothes. He has dropped from school. In fact, he is surrounded by a multitude of problems. In one of his monologues, he laments and languishes in self-condemnation:

For here I was, the eldest, and I could not find a job to fend for the family. I cannot even fend for myself. I still continue to be a burden to my already overburdened mother ... Amai thinks I'm useless. She obviously compares me with dad. Hard-working, breadwinning dad. I'm just useless. Useless and a burden to Highfields and this earth. (Samupindi, 1992:20.) 
Throughout the novel, and even when he finally joins the guerrillas, his experience of going for days without food as well as the social insecurity of his mother, brother and sisters haunts him. As a result of excessive poverty and indignity, his life becomes traumatic to the extent of passing a vote of no confidence in himself. He therefore decides to join the liberation war in order to escape the poverty and squalor at home and to redeem himself. He also wants to prove to his mother, siblings Taona, Marble and Michael, the Highfields community, and his friends that he is not a useless person. Daniel's experience of joining the war, which bears no relationship to national liberation or nationalist patriotic consciousness, is echoed in Maureen Moyo's (a former female combatant) submissions in an interview:

... so it was a way of running away from the shame, away from poverty, away from unemployment, from lack of education; away from all these things, to a place of safety ... Yes, it was a place of safety, where no one would laugh at you, no one would see you. In fact ... you hoped to come back ... to come back a better person than [the others] ... It was for selfish gain, especially for me; in my case, in my case for selfish gain, I would go there. Not that I would liberate my fellow sisters, I was not patriotic, I never looked at it that way ... I had never looked at war at a national level, I would always think of myself. (McCartney, 2000:161-162.)

These unambiguous micro historical perspectives dissect and debunk elite versions of a single patriotic history. It is certain from the above that the liberation war becomes an avenue and exercise through which characters sought to pursue their individual agendas - in this case, the restoration of a battered self-image and selfworth. It also becomes a way of escaping from the ubiquitous mortification, poverty and penury around them. Responding to Angela's question whether he joined the war as a result of poverty, Daniel says: "I suppose one might say so. But at the time I really needed to prove myself, especially to my mother. I wanted to prove that I was not totally worthless, that I could do something worthwhile, something I could be proud of." (Samupindi, 1992:151.) In the words of Baldwin (1963:67) Daniel represents

... a people from whom everything has been taken away, including, most crucially, their sense of their own worth. People can't live without this sense; they will do anything whatever to regain it. This is why the most dangerous creation of any society is that man who has nothing to lose. You do not need ten such men - one will do. 
In the same novel, Daniel is puzzled why some of his colleagues whose parents were rich and they could enjoy three meals a day joined the war. Joseph, one of the Highfields guys who crossed at the same time with Daniel came from a rich background. Peter was the son of a businessman and he had everything at his disposal. When Daniel summons courage to ask Peter why he joined the war at the time when he is breaking down, Peter says: "We ... each have ... our stories. They may be ... different, but each and every one of us has his own story ..." (Samupindi, 1992:65). Such presentations can be potentially read as conscious submissions by the author to problematise, diversify and pluralise discourse on nationalism.

Recruitment methods, especially coercion and press-ganging also reveal micro historical factors for participating in the war. Recruitment, which was closely linked to the attempt to gain national and international legitimacy and authenticity, was critical to ZANLA and ZIPRA attempts at survival. The game of numbers and the pressure from frontline and other international sympathisers forced the two nationalist armies to employ a bewildering array of recruitment drives. From this comes the realisation that people did not always go to the war voluntarily. An illustration of a case of coerced induction into the guerrilla armies comes out through Umzilakawulandelwa's experiences in a Ndebele novel by the same title, Umzilakawulandelwa (Ndlovu, 1990). In the novel, Ndlovu, the author, recounts the atrocities committed by the Rhodesian security forces on the rural masses. He vividly captures the painful experiences of the masses who were caught in between warring armies. Masses experienced unspeakable torture both at home and on the roads when travelling as they were subjected to horrendous experiences by Rhodesian forces. Through the narrator, Umzilakawulandelwa, who is a commander of a guerrilla contingent, the author also records some experiences in the rear (Zambia and Botswana) where life seems to have been better than it was at home. The novel ends with Zimbabwe attaining independence wherein it articulates the ideals of socialism, which were generally people's expectations.

Umzilakawulandelwa narrates the events surrounding his abduction together with other passengers in a bus. He is subsequently taken to Mozambique enroute to Zambia.

Kuthe ngekhefu lika-1974 ngenyanga kaMabasa, silokhusiphakathi kokunambitha lelokleza lothando, ibhasi engangihamba ngayo ngisiya ekhaya eGwanda yaphanjulwa ngabalweli benkululelo, abasehlisayo basiqhuba besisa kweleBotswana, 
lapho esathathelwa khona sayafundiswa ukuba ngabalweli benkululeko eZambia. (Ndlovu, 1990:94.)

It so happened that during the holiday of April 1974, whilst we were in the middle of savouring that episode of our love, the bus I was travelling in to Gwanda was re-routed by Freedom Fighters. They caused us to alight and then herded us to Botswana where we were recruited as freedom fighters in Zambia.

This experience underscores ZIPRA's massive recruitment drives through abduction in the Midlands and other areas south of Zimbabwe. Furthermore, the game of numbers became a debilitating pathological obsession that even undermined attempts to unify ZIPRA and ZANLA. For instance, Bhebe (1999) recalls how the unification of the two nationalist armies under the ZIPA (Zimbabwe People's Army) brand and its operational efficiency was derailed by the need to boost the numbers of recruits. He cites the example of ZIPRA where, "instead of engaging in fighting ZIPRA combatants were urged by their commanders 'that once they arrived in Rhodesia they should desert, head for Matebeleland, get recruits and then leave the country with them for Botswana, from where they would be flown to Zambia for training'" (Bhebe, 1999:64). Dabengwa (1995) also blames the collapse of the Mbeya agreement in 1967 on ZAPU which was determined not to work with ZANU because the latter was numerically in the doldrums. Many individuals became victims of these recruitment drives and the game of numbers.

In the late 1980s and beyond, the predisposition to articulate micro factors rather than macro factors is inseparable from ordinary people's struggles to be part of the national space which, for long, has been denied them by the ruling elite using nationalism as a justification for their actions. In this regard, the works

... bring out the multiple dimensions through which the [historical] and symbolical discourses of nation and the individual ... are constantly jostling for predominance. The result is an accentuated instability in meanings that further encourage the materiality of metaphor to fracture, giving birth to unforeseen narratives of the nation. (Motsa, 2006:14.)

\section{Conclusion}

The macro historical and micro historical perspectives in Zimbabwean liberation war fiction published in different epochs testify to the contesting uses to which history is put. The choice of historical ima- 
ges in certain epochs becomes an emphatic statement on the various ideological frameworks through which the subjects of nation and nationalism have been discursively broached. It is also precisely in this context that Mensah (2004:82-83) argues that

novelists have been more candid about using the past for specific purposes ... A fuller study of historical fiction would lead to a kind of taxonomy in which function, ideology and implied reader could be correlated with certain forms.

Writers' predisposition to articulate macro and micro historical factors in historical fiction offers a fertile ground for the problematised discussion on nation and nationalism. Macro historical factors are part of the official discursive paraphernalia that endorses statesanctioned perspectives of nation and nationalism. Micro historical factors, particularly in the late 1980s onwards become vigorous contestations of the early nationalist romances that sought to present a monolithic view of nationalism and nation. In this regard, they offer counter-hegemonic interpretations of nationalist discourse. Therefore, the discussion has provided unalloyed testimony that "national memory is constructed through a complex process of contestation" (He, 2007:44).

\section{List of references}

ALEXANDER, J. 2006. Legacies of violence in Matebeleland, Zimbabwe. (In Kaarsholm, P., ed. Violence, political culture and development in Africa. Oxford: Currey. p. 105-121.)

ALEXANDER, J., MCGREGOR, J. \& RANGER, T. 2000. One hundred years in the "Dark forests" of Matebeleland. Portsmouth: Heinemann.

AURET, D. 1992. Reaching for justice: the Catholic commission for justice and peace 1972-1992. Gweru: Mambo.

BALDWIN, J. 1963. The fire next time. New York: Penguin.

BHEBE, N. 1999. The ZAPU and ZANU guerrilla warfare and the Evangelical Lutheran Church in Zimbabwe. Gweru: Mambo.

BHEBE, N. \& RANGER, T., eds. 1995. Soldiers in Zimbabwe's liberation war. Vol. 1. Harare: University of Zimbabwe Publications.

CAUTE, D. 1983. Under the skin: the death of white Rhodesia. New York: Penguin.

CHIHOTA, C. 2000. When the baobab gets fat. (In Chihota, C. \& Muponde, R., eds. No more plastic balls: new voices in the Zimbabwean short story. Harare: College Press. p. 119-131.)

CHINODYA, S. 1989. Harvest of thorns. Harare: Baobab Books.

CHIWOME, E.M. \& MGUNI, Z. 2003. Zimbabwean literature in indigenous languages: crossing language barriers. Harare: University of Zimbabwe. (Unpublished book manuscript.) 
DABENGWA, D. 1995. ZIPRA in the war of national liberation. (In Bhebe, N. \& Ranger, T., eds. Soldiers in Zimbabwe's liberation war. Vol. 1. Harare: University of Zimbabwe Publications. p. 24-35.)

DAVIES, D.K. 1975. Race relations in Rhodesia: a survey for 1972-1973. London: Rex Collins.

FLEISCHMAN, S. 1983. On the representation of history in the Middle Ages. History and theory, 22(3):278-310.

FREEMAN, E.B. \& LEVSTIK, L. 1988. Recreating the past: historical fiction in the social studies curriculum. The elementary school journal, 88(4):239337.

HE, Y. 2007. Remembering and forgetting the war: elite mythmaking, mass reaction, sino-Japanese relations, 1950-2006. History and memory, 19(2):43-74.

HOFFER, E. 1955. The passionate state of mind. New York: Harper \& Row.

HUCK, C.S. 1977. Children's literature in the elementary school. 3rd ed. New York: Holt, Rinehart \& Winston.

KAARSHOLM, P. 2005. Coming to terms with violence: literature and the development of a public sphere in Zimbabwe. (In Muponde, R. \& Primorac, R., eds. Versions of Zimbabwe: new approaches to literature and culture. Harare: Weaver.)

KRIGER, N. 1992. Zimbabwe's guerrilla war: peasant voices. Cambridge: Cambridge University Press.

KRIGER, N. 2003. Guerrilla veterans in post-war Zimbabwe: symbolic and violent politics, 1980-1987. Cambridge: Cambridge University Press.

MAKATA, M. 1982. Gona reChimurenga. Gweru: Mambo.

MAZORODZE, I.V. 1989. Silent journey from the East. Harare: Zimbabwe Publishing House.

McCARTNEY, I. 2000. Maureen Moyo talks to Irene McCartney. (In Musengezi, C. \& McCartney, I., eds. Women of resilience: the voices of women excombatants. Harare: Zimbabwe Women Writers. p. 155-182.)

McLAUGHLIN, J. 1996. On the frontline: Catholic missions in Zimbabwe's liberation war. Harare: Baobab Books.

MENSAH, A. 2004. The uses of history: the historical novels from West Africa. (In Losambe, L., ed. An introduction to the African prose narrative. Trenton, Asmara: Africa World Press. p. 69-83.)

MOORCRAFT, P.L. \& McLAUGHLIN, P. 1982. Chimurenga: the war in Rhodesia 1965-1980. Marshalltown: Sygma/Collins Books.

MOTSA, Z. 2006. Charles Mungoshi: a critical reader - an introduction. (In Vambe, M. \& Chirere, M., eds. Charles Mungoshi: a critical reader. Harare: Prestige Books. p. 12-19.)

MOYO, A.C. 1985. Nguo Dzouswa. Gweru: Mambo.

MOYO, J. 1993. Civil society in Zimbabwe. Zambezia, 20(1):1-13.

MUPONDE, R. \& PRIMORAC, R., eds. 2005. Introduction: writing against blindness. (In Muponde, R. \& Primorac, R., eds. Versions of Zimbabwe: new approaches to literature and culture. Harare: Weaver. p. xiii.)

NDLOVU, B.D. 1990. Umzilakawulandelwa. Gweru: Mambo.

NHONGO-SIMBANEGAVI, J. 2000. For better or worse? Women and ZANLA in Zimbabwe's liberation struggle. Harare: Weaver.

RANGER, T. 2004. Nationalist historiography, patriotic history and the history of the nation: the struggle over the past in Zimbabwe. Journal of Southern African studies, 30(2):215-234. 
RANGER, T. 2005. Rule by historiography: the struggle over the past in contemporary Zimbabwe. (In Muponde, R. \& Primorac, R., eds. Versions of Zimbabwe: new approaches to literature and culture. Harare: Weaver. p. 217-243.)

SAMUPINDI, C. 1992. Pawns. Harare: Baobab Books.

SIGOGO, N. 1986. Ngenziwa Ngumumo Welizwe. Gweru: Mambo.

SITHOLE, M., ed. 1999. Zimbabwe: struggle-within-the-struggle (1957-1980). Harare: Rujeko.

UNESCO. 1995. Our creative diversity: report of the World Commission on Culture and Development. Paris: UNESCO.

\section{Key concepts:}

historical fiction

nation

nationalism

Zimbabwean liberation war

\section{Kernbegrippe:}

geskiedenisfiksie

nasie

nasionalisme

Zimbabwiese vryheidsoorlog 
